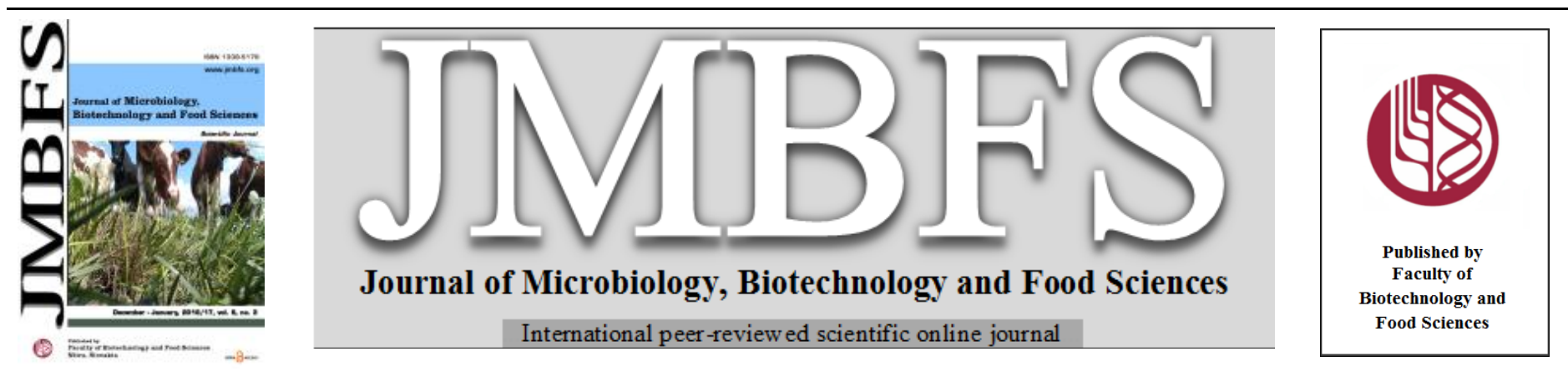

\title{
EVALUATING VIABLE CELL INDICATORS FOR FILAMENTOUS CYANOBACTERIA AND THEIR APPLICATION
}

\author{
Tylor J. Johnson ${ }^{1,2} *$, Michael B. Hildreth ${ }^{l}$, Liping Gu ${ }^{l}$, Emily L. Baldwin ${ }^{l}$, Ruanbao Zhou ${ }^{1}$, and William R. Gibbons ${ }^{l}$
}

Address(es): Dr. Tylor J. Johnson,

${ }^{1}$ Department of Biology and Microbiology, South Dakota State University, PO Box 2204A, SDM 225A, 57007, Brookings, SD, USA.

${ }^{2}$ Department of Microbiology, The University of Tennessee, 1414 W. Cumberland Ave, Knoxville, TN, 37996, USA.

*Corresponding author: tjohn141@utk.edu

doi: $10.15414 / j m b f s .2016 / 17.6 .3 .886-893$

\section{ARTICLE INFO}

Received 26.1.2016

Revised 3. 9. 2016

Accepted 3. 9. 2016

Published 1. 12. 2016

Regular article

OPEN $\partial_{\text {ACCESS }}$

\begin{abstract}
Filamentous cyanobacteria, such as Anabaena 7120 have great industrial potential due to their capability to be genetically engineered to produce next-generation biofuels while using minimal nutrients. One challenge of working with these microbes is that classical methods of quantifying cell viability are not effective due to their filamentous morphology. Therefore, fluorescent assays were evaluated to determine if they could be used as a reliable indicator of cell viability. Initially, a dual-stain assay using SYTO ${ }^{\circledR} 9$ and SYTOX ${ }^{\circledR}$ Blue was investigated. Fluorescence from SYTO $^{\circledR} 9$ was accurately correlated with viable cells; however, SYTOX ${ }^{\circledR}$ Blue did not work as a non-viable cell indicator due to non-specific binding in both viable and non-viable cells. Autofluorescence from light harvesting pigments was also evaluated as a viable cell indicator, but unfortunately these pigments resulted in several emission peaks that couldn't be captured by a single emission filter. Moreover, certain light harvesting pigments continued to fluoresce after the cell became nonviable. SYTO ${ }^{\circledR} 9$ was then compared to absorbance and chlorophyll content to quantify viable Anabaena 7120 in a chemical inhibition testing protocol. This protocol requires a low initial biomass concentration to prevent binding of the chemicals to cell biomass, and at low cell densities SYTO $^{\circledR} 9$ was superior to absorbance and chlorophyll content in quantifying viability. It was also determined that SYTO $^{\circledR} 9$ allows for the evaluation of different cultivation media on the growth of cyanobacteria in photobioreactors. SYTO 9 is a reliable, accurate indicator of viability of filamentous cyanobacteria and can be used in a high-throughput manner via a microplate reader.
\end{abstract}

Keywords: Biofuel, Chemical inhibition test, Filamentous cyanobacteria, Photobioreactor, SYTO ${ }^{\circledR} 9$

\section{INTRODUCTION}

Developing processes to produce renewable fuels and chemicals remains important, as fossil fuel reserves are finite and the adverse effects of fossil fuel generated greenhouse gases are well documented (Chen et al., 2011; Von Blottnitz and Curran, 2007). Using filamentous cyanobacteria for this purpose is an attractive option as they are capable of producing biofuels and chemicals from $\mathrm{CO}_{2}$ and solar energy (Machado and Atsumi, 2012). For example, filamentous cyanobacteria have already been engineered to produce nextgeneration biofuels such as limonene (Halfmann et al., 2014a), farnesene (Halfmann et al., 2014b), and linalool (Gu et al., 2012). Many strains of filamentous cyanobacteria are also diazotrophic, using specialized cells called heterocysts to fix atmospheric nitrogen. These attributes have led to cyanobacteria emerging as a promising platform organism for production of fuels and chemicals (Schoepp et al., 2014).

Classical methods of monitoring cell viability, such as viable cell counts and flow cytometry, will not work for filamentous cyanobacteria due to their filamentous morphology (Johnson et al., 2015). Sarchizian and Ardelean (2012) do report using the direct viable count method with epi-fluorescence microscopy on filamentous cyanobacteria isolated from a mesothermal spring for quantification of viable cells. However, many strains of filamentous cyanobacteria tend to aggregate in liquid media making accurate direct counts via microscopy quite difficult. Cell viability information is critical for research purposes (e.g., screening mutants for increased tolerance to biofuels they are engineered to produce), as well as to monitor cyanobacteria performance in photobioreactor (PBR) systems (Jin et al., 2014).

One potential option for quantifying viability of filamentous cyanobacteria is the LIVE/DEAD $^{\circledR}$ BacLight $^{\mathrm{TM}}$ Bacterial Viability Kit (Life Technologies $^{\mathrm{TM}}$, Carlsbad, CA, USA), which has been successfully used to quantify viability of several types of bacteria (Magajna and Schraft, 2015; Zeidán-Chuliá et al., 2015), including cyanobacteria (Zhu and Xu, 2013). Previously, we determined that this kit does not allow accurate viability estimates of filamentous cyanobacteria, since the non-viable cell indicator propidium iodide (PI) also crossed the intact membranes of viable filamentous cyanobacteria, thereby leading to erroneous results (Johnson et al., 2015). Thus, alternative methods to quantify viability in filamentous cyanobacteria need to be developed.

SYTOX $^{\circledR}$ Blue is one of several SYTOX ${ }^{\circledR}$ Dead Cell Stains that should not be able to cross intact cell membranes. This fluorochrome has been successfully used to quantify non-viable cells in bioaggregates (Chen et al., 2007) and in aerobic granules (Adav et al., 2007a). In this study, SYTOX ${ }^{\circledR}$ Blue was tested as a method to quantify non-viable filamentous cyanobacteria. To attempt to quantify viability in filamentous cyanobacteria, autofluorescence from the light harvesting pigments phycobiliproteins (PBS) and chlorophyll $\alpha$ were also tested in this study. Fluorescence from the viable cell indicator SYTO ${ }^{\circledR} 9$ was compared to absorbance and chlorophyll $\alpha$ content to determine which is a superior method for monitoring viability in conditions even when biomass content is minimal. Finally, SYTO 9 was evaluated for monitoring the effect of different cultivation media on cyanobacterial growth in 40 L PBRs.

\section{MATERIALS AND METHODS}

\section{Microbial strains, maintenance, and culture conditions}

The filamentous, diazotrophic cyanobacterial strain Anabaena sp. PCC 7120, a model species for cyanobacteria (Bryant, 2006; Rippka et al., 1979), was obtained from the Pasteur Culture Collection (Paris, France). In our previous study, 3 strains of filamentous cyanobacteria were investigated and all had similar results regarding interactions with viable cell indicators (Johnson $\boldsymbol{e t}$ al., 2015). Therefore, in this study we only investigated Anabaena 7120, but are confident the results described herein would be similar for most diazotrophic strains of filamentous cyanobacteria. A putative spontaneous mutant of Anabaena 7120, referred to hereafter as A7120.(0.32t).farn, was isolated during prior directed evolution trials in which Anabaena 7120 was acclimated to $0.32 \mathrm{~g} / \mathrm{L}$ farnesene (Johnson et al., 2016a). For long term storage, strains were frozen at $80^{\circ} \mathrm{C}$ in $5 \% \mathrm{v} / \mathrm{v}$ methanol. For short term maintenance, the cyanobacteria were grown on BG11 agar (1.5\% agar) (Allen and Stanier, 1968) at pH 7.1 and 
incubated at room temperature under constant illumination of $24 \mu \mathrm{E} \mathrm{m}^{-2} \mathrm{~s}^{-1}$, and then stored at room temperature. Light intensities were measured with a Heavy Duty Light Meter with PC Interface (Extech Intsruments, Waltham MA, USA). In the experiments described below, cyanobacterial cultures were grown either in $27 \mathrm{ml}$ screw capped test tubes, $250 \mathrm{ml}$ Erlenmeyer flasks, or in $40 \mathrm{~L}$ PBRs. The $27 \mathrm{ml}$ test tubes had an open top cap with PTFE/silicone septa to allow inoculation and sampling via syringe and needles, and yet prevent the loss of volatile chemicals that were being tested for cell toxicity. Tubes were filled with $\sim 27 \mathrm{ml} \mathrm{BG11}$ with $20 \mathrm{mM}$ HEPES buffer and $0.5 \mathrm{~g} / \mathrm{L} \mathrm{NaHCO}_{3}$ for a carbon source. The tubes were incubated at room temperature under constant illumination of approximately $24 \mu \mathrm{E} \mathrm{m}^{-2} \mathrm{~s}^{-1}$ using fluorescent lights while rotating at $8 \mathrm{rpm}$ in a Thermo Fisher Scientific ${ }^{\mathrm{TM}}$ Labquake $^{\mathrm{TM}}$ Tube Rotator (Thermo Fisher Scientific ${ }^{\mathrm{TM}}$, Waltham, MA, USA). The $250 \mathrm{ml}$ Erlenmeyer flask trials contained $100 \mathrm{ml}$ of BG11 broth at pH 7.1 supplemented with $20 \mathrm{mM}$ HEPES buffer. Flasks were stoppered with a foam stopper and the opening was covered with aluminum foil. The flasks were incubated in a Lab-Line ${ }^{\circledR}$ Incubator-Shaker (Lab-Line ${ }^{\circledR}$ Instruments, Melrose Park, IL, USA) at $30^{\circ} \mathrm{C}$ and $100 \mathrm{rpm}$ under constant illumination of $19 \mu \mathrm{E} \mathrm{m}^{-2} \mathrm{~s}^{-1}$ using fluorescent lights.

PBR trials were conducted in $40 \mathrm{~L}$ transparent fiberglass flat bottom tanks (Solar Components Corp., Manchester, NH, USA) that were sparged from the bottom with a mixture of $95-5 \%$ air- $\mathrm{CO}_{2}$ at a rate of $0.25 \mathrm{~L} / \mathrm{L} / \mathrm{min}$. The culture medium consisted of $30 \mathrm{~L}$ of cultivation medium and was inoculated with $1.5 \mathrm{~L}(5 \%)$ of an Anabaena 7120 culture that had been grown to mid-log phase. The reactors were incubated at room temperature $\left(20-22^{\circ} \mathrm{C}\right)$ under constant illumination of approximately $40 \mu \mathrm{E} \mathrm{m}^{-2} \mathrm{~s}^{-1}$ using fluorescent lights until $\sim 2$ days after stationary phase was reached.

\section{Statistical analyses}

To conduct post hoc power analysis and to ensure the sample size of each treatment was large enough to achieve statistical power of $\geq 0.95$, the $G^{*}$ Power statistical power analysis program was utilized (Faul et al., 2007). To determine if significant differences existed among the treatments (different cultivation media) on filamentous cyanobacterial growth, a one-way ANOVA was performed using the $\mathrm{R}$ statistical software program (R Core Team, 2013). If it was determined by the ANOVA that significant differences did occur, then the Tukey's test was performed to determine among which treatments the statistical differences occurred.

\section{Evaluating SYTOX ${ }^{\circledR}$ Blue and SYTO $^{\circledR} 9$ as a dual-stained assay to quantify viability}

SYTOX $^{\circledR}$ Blue and SYTO $^{\circledR} 9$ were purchased from Thermo Scientific (Waltham, MA, USA). In a previous study by our research group, it was determined that SYTO $^{\circledR} 9$ stains viable filamentous cyanobacteria cells as expected (Johnson $\boldsymbol{e}$ al., 2015). To determine if SYTOX ${ }^{\circledR}$ Blue fluoresces non-viable cyanobacterial cells at the expected excitation/emission wavelengths, $1 \mathrm{ml}$ of a mid-log phase culture of Anabaena 7120 was chemically killed by exposing it to $10 \mathrm{ml}$ of $70 \%$ isopropanol in a $15 \mathrm{ml}$ conical test tube that was incubated at room temperature for $1 \mathrm{~h}$ with manual mixing every $15 \mathrm{~min}$. The cells were then recovered by centrifuging at $10,000 \mathrm{rpm}$ for $10 \mathrm{~min}$ at room temperature. The cell pellet was then washed in $1 \mathrm{ml} \mathrm{BG11}$ and centrifuged at $10,000 \mathrm{rpm}$ for $1 \mathrm{~min}$ at room temperature. Next, the washing step was repeated two additional times and the final cell pellet was resuspended in $1 \mathrm{ml}$ BG11. SYTOX ${ }^{\mathbb{B}}$ Blue was added to the cell suspension at a final concentration of $5 \mu \mathrm{M}$. A $100 \mu 1$ aliquot of the culture was then transferred to a microscope slide for examination by a Cytation ${ }^{\mathrm{TM}} 3 \mathrm{Cell}$ Imaging Multi-Mode reader (BioTek ${ }^{\circledR}$ Instruments, Inc., Winooski, VT, USA). Cyanobacterial cells were observed for fluorescence in the blue spectra by the reader at the maxima excitation/emission for SYTOX $^{\circledR}$ Blue when the dye is bound to DNA $(444 / 480 \mathrm{~nm})$.

To evaluate a dual-stain assay using SYTO $^{\circledR} 9$ (for viable cells) and SYTOX Blue (for non-viable cells), Anabaena 7120 was grown to mid-log phase in a 250 $\mathrm{ml}$ Erlenmeyer flask under the conditions described above. The following protocol was adapted from Johnson $\boldsymbol{e t}$ al., (2015). Ten $\mathrm{ml}$ of the culture was transferred to a $15 \mathrm{ml}$ conical and processed as shown in Figure 1 to obtain solutions containing equal numbers of viable and non-viable cells. The solutions were mixed in $2 \mathrm{ml}$ ratios of 0:100, 10:90, 50:50, 90:10, and 100:0. In this study, SYTOX $^{\circledR}$ Blue was used as a replacement for PI as a non-viable cell indicator. In this assay, per the manufacturer's protocol (Molecular Probes, 2004), mid-log cyanobacterial culture is assumed to contain $100 \%$ viable cells. Obviously this isn't entirely accurate, but is the basis of the assay that has been used successfully in previous studies (Adav et al., 2007a; Chen et al., 2007). One hundred $\mu 1$ of viable: non-viable cell solutions were pipetted into wells of a 96-well plate in triplicate. SYTO ${ }^{\circledR} 9$ and SYTOX $^{\circledR}$ Blue were added to each well at a concentration of $5 \mu \mathrm{M}$ for each stain. The plates were then wrapped in aluminum foil and incubated in the dark at room temperature for $15 \mathrm{~min}$. After incubation, fluorescence was measured by a Synergy 2 Multi-Mode Microplate Reade (BioTek $^{\circledR}$, Winooski, VT, USA). To measure green fluorescence from SYTO $^{\circledR} 9$ stained cells, a fluorescence filter with excitation wavelength $485 \pm 20 \mathrm{~nm}$ emission wavelength $528 \pm 20 \mathrm{~nm}$ was used. To measure blue fluorescence from
SYTOX $^{\circledR}$ Blue stained cells, a fluorescence filter with excitation wavelength 440 $\pm 30 \mathrm{~nm}$; emission wavelength $485 \pm 10 \mathrm{~nm}$ was used. For each trial, an empty well was used as a negative control to ensure the microplate reader was working properly.

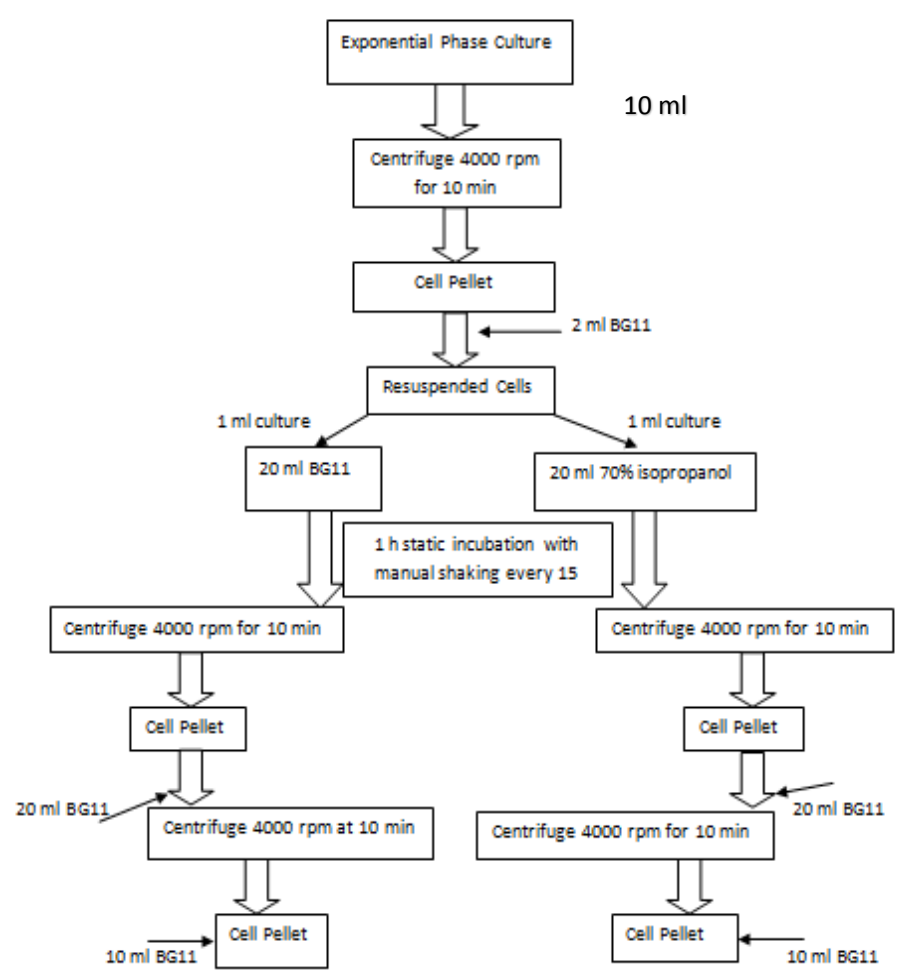

Figure 1 Process used to prepare viable and non-viable cells for use in developing calibration curve

Figure adapted from Johnson et al., (2015). The resulting samples were mixed in ratios of 0:100, 10:90, 50:50, 90:10, and 100:0. (Isopropyl alcohol used to make cells non-viable).

Linear regression was performed to plot the ratio of green and blue fluorescence $v s$. cell viability percentage. The data was analyzed by dividing the green fluorescence $(\mathrm{F})$ emitted $(\mathrm{em})$ by the blue fluorescence emitted, (Ratio $\mathrm{G}_{\mathrm{B}}=$ $\mathrm{F}_{\text {cell,em } 1} / \mathrm{F}_{\text {cell,em2} 2}$ ). The ratio was plotted as Ratio $\mathrm{G}_{\mathrm{G} / \mathrm{B}}$ versus cell viability percentage. Linear regression analysis was performed to calculate and assess the correlation coefficient.

To further investigate SYTOX ${ }^{\circledR}$ Blue as a non-viable cell indicator, fluorescence data was analyzed from the microplate reader. Each well contained $100 \mu \mathrm{l}$ of either Anabaena 7120 or BG11, as well as both SYTO ${ }^{\circledR} 9$ and SYTOX ${ }^{\circledR}$ Blue, or one stain individually at a final concentration of $5 \mu \mathrm{M}$. An empty well was used as a control to ensure the microplate reader was working properly. To measure fluorescence from the stains, the filters that were described above were used.

\section{Comparison of $\mathrm{SYTO}^{\circledR} 9$ and autofluorescence as viable cell indicators}

To compare SYTO ${ }^{\circledR} 9$ and autofluorescence as viability assays in filamentous cyanobacteria, a 40 L PBR containing $30 \mathrm{~L} \mathrm{BG11}$ was inoculated as described above. The inoculum had been grown in a $4 \mathrm{~L}$ Erlenmeyer flask containing $2 \mathrm{~L}$ BG11 in a Lab-Line ${ }^{\circledR}$ Incubator-Shaker under the conditions described above. After inoculation, the PBR was incubated under the conditions described above, and samples were taken daily for absorbance $\left(\mathrm{OD}_{700}\right)$ and viability until stationary phase was reached. The samples were taken from a homogenous suspension in the PBR caused by air sparging from the bottom of the reactor. For absorbance, $1 \mathrm{ml}$ samples were measured using a Thermo Fisher Scientific ${ }^{\mathrm{TM}}$ Genesys 10S UV-Vis Spectrophotometer (Thermo Fisher Scientific ${ }^{\mathrm{TM}}$, Waltham, MA, USA).

To measure viability via $\mathrm{SYTO}^{\circledR} 9,100 \mu 1$ samples were transferred to a 96 -well plate and $\mathrm{SYTO}^{\circledR} 9$ was added to each well at a concentration of $5 \mu \mathrm{M}$. Fluorescence was then measured by the microplate reader using the excitation/emission wavelength spectra described above. For viability measurements via autofluorescence, $100 \mu \mathrm{l}$ samples were transferred to a 96-well plate. There are various wavelengths used in the literature, for example, various emission spectra have been used for chlorophyll $\alpha$ determination, including 681 nm, (Guzmán et al., 2015) $672 \mathrm{~nm}$, (Lozano et al., 2013) and $660 \mathrm{~nm}$ (Ogawa and Sonoike, 2015). Also, PBS have fluorescent peaks at 635, 645, 654, 659, and 
$673 \mathrm{~nm}$ (Gryliuk et al., 2014). Thus, several excitation/emission filters were tested on the microplate reader to determine which yielded the greatest fluorescence intensity of a mid-log phase culture of Anabaena 7120. The filters tested were (excitation/emission): $520 \pm 20 / 620 \pm 40 ; 485 \pm 20 / 620 \pm 40 ; 540$ $\pm 25 / 620 \pm 40$ (all units $=\mathrm{nm})$.

\section{Assessing cell viability in a chemical inhibition test}

To investigate if fluorescence from $\mathrm{SYTO}^{\circledR} 9$ allows for the screening of putative filamentous cyanobacterial mutants that potentially have developed an increased tolerance to toxic chemicals, $\mathrm{SYTO}^{\circledR} 9$ stain was evaluated for use in measuring the viability of filamentous cyanobacteria that were exposed to farnesene in chemical inhibition tests. Farnesene is volatile (Asai et al., 2016; Ruther and Hilker, 1998), thus screening and acclimation trials needed to be conducted in sealed test tubes to maintain a constant titer of the chemical. As no atmospheric $\mathrm{CO}_{2}$ was able to enter the test tube, $0.5 \mathrm{~g} / \mathrm{L} \mathrm{NaHCO}$ was added to the $\mathrm{BG} 11$ medium after autoclaving to serve as the carbon source (Hailing-Sørensen $\boldsymbol{e t}$ al., 1996; Johnson et al., 2016c; Mayer et al., 2000).

Twenty-seven ml test tubes containing $\sim 27 \mathrm{ml}$ of $\mathrm{NaHCO}_{3}$-supplemented BG11, along with $0.032 \mathrm{~g} / \mathrm{L}$ farnesene, were inoculated with $270 \mu \mathrm{l}(1 \%)$ of either a mid-log phase Anabaena 7120 culture or a putative spontaneous mutant A7120(0.32t).farn. Cultures were incubated under conditions described above. Daily samples were taken via a needle and syringe in order to maintain constant titers of farnesene. For viability determinations, $100 \mu 1$ samples were transferred to a microplate. SYTO ${ }^{\circledR} 9$ was added to each well at a concentration of $5 \mu \mathrm{M}$, and fluorescence was determined as described above. Absorbance and chlorophyll $\alpha$ were measured by diluting $100 \mu 1$ samples with $900 \mu 1$ BG11 in a cuvette. Absorbance was measured at an optical density (OD) of $700 \mathrm{~nm}$. Chlorophyll $\alpha$ was determined using the equation: $\mathrm{Chl} \alpha$ content $(\mu \mathrm{g} / \mathrm{ml})=14.96\left(\mathrm{OD}_{678}-\right.$ $\left.\mathrm{OD}_{750}\right)-0.616\left(\mathrm{OD}_{720}-\mathrm{OD}_{750}\right)$, and the protocol described by Guoce $\boldsymbol{e t}$ al . (2011).

\section{Assessing cell viability in photobioreactors}

To investigate if fluorescence from SYTO $^{\circledR} 9$ allows for the comparison of different treatments on the viability of filamentous cyanobacteria in PBRs, Anabaena 7120 was cultivated in various growth media. The cultivation media evaluated were as follows: BG11 (standard BG11 includes sodium nitrate), BG11 supplemented with urea rather than sodium nitrate $\left(\mathrm{BG} 11_{\mathrm{U}}\right), \mathrm{BG} 11$ without a nitrogen source $\left(\mathrm{BG} 11_{0}\right)$, and tap water. The cultivation media containing nitrogen sources (BG11 and BG11 $\mathrm{U}_{\mathrm{U}}$ ) contained $0.248 \mathrm{~g} / \mathrm{L}$ nitrogen. The PBRs described above were inoculated with $1.5 \mathrm{~L}(5 \%)$ of a mid-log phase culture of Anabaena 7120. The PBRs were incubated in the conditions previously above described. For daily viability determinations, $100 \mu \mathrm{l}$ samples were transferred to a 96-well microplate. SYTO ${ }^{\circledR} 9$ was then added to each well at a concentration of $5 \mu \mathrm{M}$, and fluorescence was determined as described above.

\section{RESULTS AND DISCUSSION}

\section{Evaluating SYTOX $^{\circledR}$ Blue and SYTO $^{\circledR} 9$ as a dual-stain assay for quantifying viability}

SYTOX $^{\circledR}$ Blue is a nucleic acid binding fluorochrome commonly used to stain non-viable bacterial cells, as it should not be able to penetrate an intact cell membrane (Adav and Lee, 2008; Krause et al., 2007; Truernit and Haseloff, 2008). SYTO $^{\circledR} 9$ is a fluorescent dye capable of penetrating most cellular membranes, causing all cells containing nucleic acids to fluoresce green (Lee and Rhee, 2001; Shi et al., 2007). SYTOX ${ }^{\circledR}$ Blue was used as an alternative to the non-viable cell indicator PI. PI was previously shown by Johnson $\boldsymbol{e t}$ al., (2015) to not function properly as a non-viable cell indicator in filamentous cyanobacteria because it also stained viable cells. We postulated that this was due to intercellular channels that allow nutrient passage between cells in the filaments (Mullineaux et al., 2008)

Previously, we had confirmed that SYTO $^{\circledR} 9$ caused viable Anabaena 7120 cells to fluoresce in the green spectra (Johnson et al., 2015). Using the Cytation ${ }^{\mathrm{TM}} 3$ microplate reader, we confirmed that SYTOX ${ }^{\circledR}$ Blue caused non-viable Anabaena 7120 cells to fluoresce in the blue spectra (data not shown). These observations were consistent with other studies and information from the stain's manufacturer (Adav et al., 2007b; Chen et al., 2007; Filoche et al., 2007; Sato et al., 2004; Zhu and $X u, 2013$ )

To determine if a dual-stain assay consisting of SYTO ${ }^{\circledR} 9$ and SYTOX ${ }^{\circledR}$ Blue is capable of accurately quantifying the viability of filamentous cyanobacteria, calibration curves were generated to correlate the ratio of green $\left(\mathrm{SYTO}^{\circledR} 9\right.$, viable cells) to blue (SYTOX ${ }^{\circledR}$ Blue, non-viable cells) fluorescence against known mixtures of viable and non-viable cells. Figure 2 shows the plots and regression lines for 3 trials. All trials had high $\mathrm{R}^{2}$ values $(0.96-0.98)$. Trials $1(\mathrm{~m}=0.0129)$ and $3(\mathrm{~m}=0.0101)$ had similar slopes, compared to Trial $2(\mathrm{~m}=0.006)$. Trials 1 $(b=0.7186)$ and $2(b=0.8457)$ had virtually identical y-intercepts compared to Trial $3(b=1.6693)$. The variability in the results between the 3 trials indicated that there was a problem with the dual-stain assay.

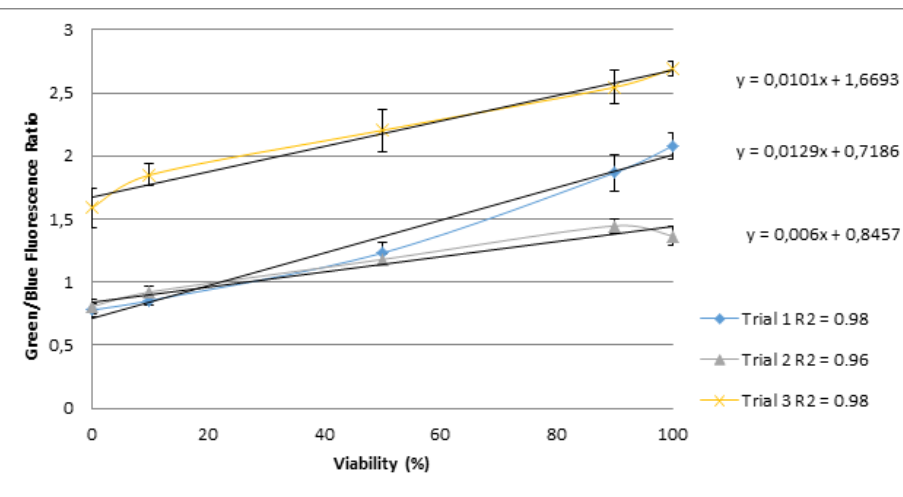

Figure 2 Viability $v s$. green/blue fluorescence ratios for Anabaena sp. PCC 7120

In each trial, triplicate SYTO $^{\circledR} 9$ green and SYTOX $^{\circledR}$ blue fluorescence measurements were taken for each mixture of viable and non-viable cells. This data was used to calculate the green/blue fluorescence ratio. Error bars represent the standard deviation. The black lines represent the least-squares fit.

To investigate why the correlation equations were not identical for the 3 trials shown in Figure 2, we assessed the underlying data. Figure 3 shows the separate plots for green $\left(\mathrm{SYTO}^{\circledR} 9\right)$ and blue $\left(\mathrm{SYTOX}^{\circledR}\right.$ Blue) fluorescence $v s$. \% viability from Trial 1 (Trial 2 and Trial 3 had virtually identical results to Trial 1), as well as the calculated ratio. Fluorescence from the $\mathrm{SYTO}^{\circledR} 9$ stain provided the expected positive slope of green fluorescence intensity over percent viability. However, fluorescence from the SYTOX ${ }^{\circledR}$ Blue stain resulted in a relatively flat slope instead of the anticipated strong negative slope. The flat slope indicates that SYTOX $^{\circledR}$ Blue was staining both non-viable and viable cells, which is similar to what occurred with PI in filamentous cyanobacteria (Johnson et al., 2015). Thus, it appears that the SYTO $^{\circledR} 9$ and SYTOX $^{\circledR}$ Blue dual-stain assay is not precise in this application. Other researchers have noted the occurrence of misinterpretations in live/dead staining results for various reasons (Bridier $\boldsymbol{e t}$ al., 2015; Johnson and Criss, 2013; Lu et al., 2014; Stiefel et al., 2015).

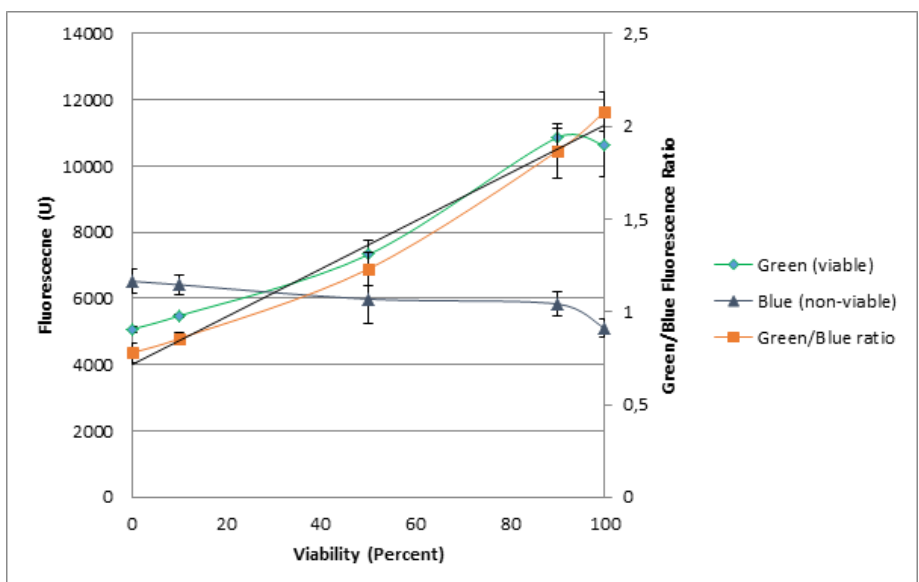

Figure 3 Viability assessed by green (viable) and blue (non-viable) fluorescence for Anabaena sp. PCC 7120

Each data point represents the average of triplicate readings, and error bars represent the standard deviation. This data was used to calculate the green/blue fluorescence ratio, which is also shown, along with the least-squares fit line (black line)

To ensure that the BG11 medium and the BG11 medium with fluorochromes added was not the cause of inaccuracy in the dual-stain assay, raw data from the microplate reader was also analyzed for samples containing the medium only, as well as the medium with $100 \%$ viable cells (Table 1). For green fluorescence, the average fluorescence intensity readings (arbitrary unit: U) were 433 for the empty well, which was considered background fluorescence. For BG11 + SYTO $^{\circledR} 9$ the average intensity was $1,835 \mathrm{U}$, which is about $4 \mathrm{x}$ higher than the empty well and represents the baseline green fluorescence of the medium and the $\mathrm{SYTO}^{\circledR} 9$ dye BG11 + SYTOX ${ }^{\circledR}$ Blue average intensity was $325 \mathrm{U}$, which suggested that the SYTOX $^{\circledR}$ Blue dye did not provide any green fluorescence, since the intensity was approximately the same as the background fluorescence reading. BG11 + SYTO $^{\circledR} 9+$ SYTOX $^{\circledR}$ Blue resulted in a fluorescence reading of $1,767 \mathrm{U}$, which was approximately the same as observed when just SYTO $^{\mathbb{R}} 9$ was added. The data from the controls described above is what would be expected. 
Table 1 Microplate readings of Anabaena sp. PCC 7120 evaluating fluorescence intensity [arbitrary units (U)] of SYTO® 9 and SYTOX Blue Averages and standard deviations are representative of a triplicate.

\begin{tabular}{lccccccc}
\hline & Empty Well & $\begin{array}{c}\text { BG11 }+ \text { SYTO } \\
9\end{array}$ & $\begin{array}{c}\text { BG11 + } \\
\text { SYTOX Blue }\end{array}$ & BG11 + 2 dyes & $\begin{array}{c}\text { Anabaena 7120 + } \\
\text { SYTO 9 }\end{array}$ & $\begin{array}{c}\text { Anabaena 7120 } \\
+ \text { SYTOX Blue }\end{array}$ & $\begin{array}{c}\text { Anabaena 7120 + } \\
\text { 2 dyes }\end{array}$ \\
\hline SYTO $^{\circledR}$ 9 (Ex 485 \pm 10 & 433.00 & 1835.00 & 325.33 & 1767.00 & 26585.33 & 303.00 & 28218.67 \\
Em 528 $\pm 20 \mathrm{~nm})$ & \pm 9.84 & \pm 84.18 & \pm 9.71 & \pm 105.51 & \pm 1373.56 & \pm 6.92 & \pm 2752.60 \\
SYTOX $($ Ex 440 & & & & 4160.00 & 4609.00 & 3051.33 & 6111.00 \\
Em 485 $\pm 10 \mathrm{~nm})$ & 2745.67 & 2095.00 & 1830.33 & \pm 898.86 & \pm 354.23 & \pm 109.74 & \pm 544.47 \\
\hline
\end{tabular}

Viable Anabaena 7120 cells in BG11 + SYTO $^{\circledR} 9$ yielded an intensity of 26,585 $\mathrm{U}$, and this high green fluorescence reading strongly suggested that $\mathrm{SYTO}^{\circledR} 9$ accurately measured viable cells. Anabaena 7120 in BG11 + SYTOX $^{\circledR}$ Blue resulted in a reading of only $303 \mathrm{U}$, which was approximately the same as the background fluorescence reading. Thus, the SYTOX ${ }^{\circledR}$ Blue dye did not provide any green fluorescence. Anabaena 7120 in BG11+ SYTO $^{\circledR} 9+$ SYTOX $^{\circledR}$ Blue yielded a reading of $28,218 \mathrm{U}$, and this green fluorescence intensity was approximately the same as observed when only SYTO $^{\circledR} 9$ was added. The above data yielded from the treatments with viable cells was expected. Therefore, we concluded that $\mathrm{SYTO}^{\circledR} 9$ and the resulting green fluorescence correlate accurately with cell viability, and SYTOX $^{\circledR}$ Blue does not interfere with the green fluorescence.

For blue fluorescence, the average fluorescence intensity for the empty well was $2,745 \mathrm{U}$, which was background fluorescence. BG11 + SYTO $^{\circledR} 9$ yielded an intensity of 2,095 U, which suggested that the SYTO $^{\circledR} 9$ dye did not provide any blue fluorescence, since the intensity was $\sim 25 \%$ lower than the background fluorescence reading. The data also showed that the background fluorescence intensity decreased when the culture medium was added to the well. BG11 + SYTOX $^{\circledR}$ Blue resulted in an intensity of $1,830 \mathrm{U}$, which was $\sim 33 \%$ less than the background fluorescence reading, but almost identical to the BG11 $+\mathrm{SYTO}^{\circledR} 9$ reading. Therefore, we concluded that this SYTOX ${ }^{\circledR}$ Blue dye by itself did not add any additional blue fluorescence, which was expected as the stain is supposed to only yield blue fluorescence when bound to DNA or RNA (Estevez et al., 2011).

As BG11 + SYTO $^{\circledR} 9$ and BG11 + SYTOX $^{\circledR}$ Blue yielded virtually identical blue fluorescence, it can be concluded that neither stain contributes to blue fluorescence, and that BG11 medium causes a decrease in background fluorescence compared to the empty well. BG11 + SYTO $^{\mathbb{P}} 9+$ SYTOX $^{\mathbb{B}}$ Blue fluorescence intensity was $4,160 \mathrm{U}$, and this intensity was higher than what was observed due to the background or presence of either SYTO ${ }^{\circledR} 9$ or SYTOX ${ }^{\circledR}$ Blue alone. The data from this part of the experiment is logical as the summation of blue fluorescence from BG11 + SYTO $^{\circledR} 9$ and BG11 + SYTOX $^{\circledR}$ Blue $(3,925 \mathrm{U})$ was virtually identical to fluorescence from BG11+ SYTO $^{\circledR} 9+$ SYTOX $^{\circledR}$ Blue (4,160 U).

Viable Anabaena 7120 in BG11 + SYTO $^{\circledR} 9$ yielded a fluorescence of 4,609 U, which was approximately double of what was observed in the same test without viable cells present. The green fluorescence from viable cells in BG11 + SYTO 9 was $26,585 \mathrm{U}$. The high intensity of this fluorescence, coupled with the close proximity of green and blue on the light scale, was the reason for this increase in background fluorescence. Anabaena 7120 in BG11 + SYTOX $^{\circledR}$ Blue intensity was $3,051 \mathrm{U}$, which was $1,200 \mathrm{U}$ higher than in the same test without viable cells present. Similar results were also observed with PI in our previous study, and was confirmed via microscopy to be caused by PI binding to nucleic acids in viable cells (Johnson et al., 2015). Since PI and SYTOX ${ }^{\circledR}$ Blue have identical modes of action for staining non-viable cells, this study strongly suggests that SYTOX Blue was staining viable cells, otherwise the fluorescence intensity wouldn't have increased.

Anabaena 7120 in BG11+ SYTO $^{\circledR} 9+$ SYTOX $^{\circledR}$ Blue resulted in a fluorescence intensity of $6,111 \mathrm{U}$, which was $~ 50 \%$ higher than in the same test without viable cells present. Again, this suggests SYTOX ${ }^{\circledR}$ Blue was staining viable cells, however the presence of SYTO $^{\circledR} 9$ may have also contributed to this increase as it did in the identical treatment without cells. The above data from the treatments with viable cells is not what would be expected. Thus, it can be concluded that SYTOX $^{\circledR}$ Blue also stains viable filamentous cyanobacterial cells, which is a similar result to what we observed with PI (another non-viable cell indicator) in filamentous cyanobacteria (Johnson et al., 2015).

Both PI and SYTOX ${ }^{\circledR}$ Blue have now been shown to be ineffective as non-viable cell indicators with filamentous cyanobacteria. Thus, it can be assumed that none of the other SYTOX ${ }^{\circledR}$ dead cell stains will work for this purpose as they are all supposed to be impermeant to viable cell membranes. This conclusion concurs with a study by Sato et al. (2004) in which strong correlations between expected and measured values in mixtures of live and dead Anabaena 7120 cells could not be made when SYTOX ${ }^{\circledR}$ Green was the non-viable cell indicator.

While, the SYTOX ${ }^{\circledR}$ Dead Cell Stains have been showed to work with certain species of cyanobacteria (Sato et al., 2004; Zhu and Xu, 2013), none were heterocyst-forming strains of filamentous cyanobacteria. Tashyreva et al. (2013) report using a SYTOX $^{\circledR}$ dead cell stain to stain Phormidium populations.
However, this stain was not used in conjunction with $\mathrm{SYTO}^{\circledR} 9$, thus the results cannot be compared. Using SYTO $^{\circledR} 9$ and SYTOX ${ }^{\circledR}$ Blue as a dual-stain viability assay does not work as expected with filamentous cyanobacteria, however this experiment showed evidence that fluorescence from $\mathrm{SYTO}^{\circledR} 9$ appeared to be an accurate viable cell indicator of filamentous cyanobacteria.

Comparison of $\mathrm{SYTO}^{\circledR}$ 9, absorbance, and autofluorescence as viable cell indicators

Cyanobacteria are known to autofluoresce in the red spectrum (Caiola et al., 1996; Dagnino et al., 2006) when excited in the green spectrum due to chlorophyll $\alpha$ (Aiken, 1981; Lichtenthaler et al., 1986) and PBS (Baier et al., 2004). We hypothesized that autofluorescence from these light harvesting pigments could be used to assess cell viability, with the additional benefit that no external stains would be needed. The complicating factor of this approach is that photosynthetic pigments can have multiple emission wavelengths. For example, various emission spectra have been used for chlorophyll $\alpha$ determination, including $681 \mathrm{~nm}$, (Guzmán et al., 2015) $672 \mathrm{~nm}$, (Lozano et al., 2013) and 660 nm (Ogawa and Sonoike, 2015). Also, PBS have fluorescent peaks at 635, 645, 654, 659, and $673 \mathrm{~nm}$ (Gryliuk et al., 2014). For this study, filters with several wavelengths were tested on a mid-log culture of cyanobacteria and it was determined than an excitation wavelength of $540 \pm 25 \mathrm{~nm}$ and an emission wavelength of $620 \pm 40 \mathrm{~nm}$ yielded the highest fluorescence values.

Figure 4 shows that SYTO ${ }^{\circledR} 9$ is a better indicator of viability of filamentous cyanobacteria than autofluorescence from light harvesting pigments. While there are a couple data points in the $\mathrm{SYTO}^{\circledR} 9$ plot that cause the plot to not have the standard smooth sigmoidal shape expected with microbial growth curves, this plot has a similar shape to another plot in the literature, where SYTO ${ }^{\mathbb{B}} 9$ was used to monitor cell viability of a microorganism (Yagüe et al., 2010). Both plots have data points that alter the expected smooth shape of the plot, yet still allow for adequate interpretation of the growth dynamic that is occurring.

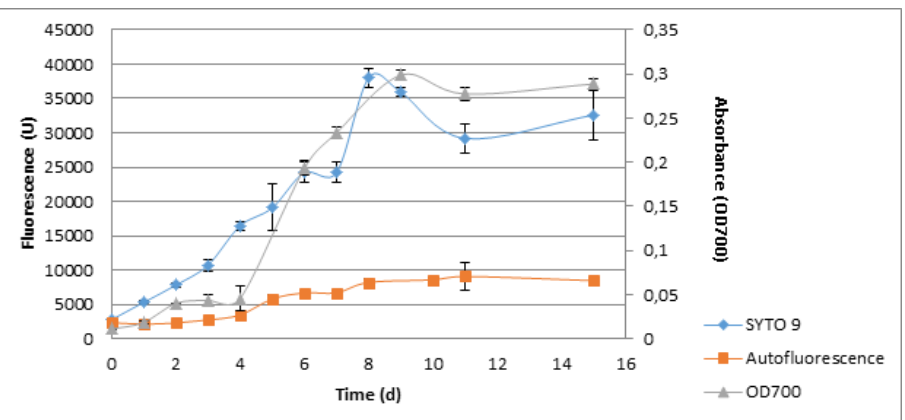

Figure 4 Comparison of two viability assays against absorbance for quantification of Anabaena sp. PCC 7120 in a 40 L PBR. The data represents the mean $(n=3)$. Error bars represent the standard deviation.

A possible reason for the weak autofluorescence in Figure 4 was that the emission peaks from each of the pigments is different, thus the assay loses sensitivity. Another reason could be that there are no differences in fluorescence from the pigments in viable vs. non-viable cells. Regardless of the reason, autofluorescence from light harvesting pigments is not a reliable indicator of viability. This concurs with a study by Sato et al. (2004), which concluded that the intensity of fluorescence from the light harvesting pigments was not related to the relative percentages of viable $v s$. non-viable cells. The fact that the plot generated from fluorescence from $\mathrm{SYTO}^{\circledR} 9$ is similar to the plot generated by absorbance readings provides further evidence that $\mathrm{SYTO}^{\circledR} 9$ can be used as a reliable indicator of viability in filamentous cyanobacteria.

\section{Assessing cell viability in a chemical inhibition test}

High cell densities can affect the bioavailability and toxicity of chemicals that are being assessed for cell toxicity. This is caused by the adsorption of the chemical onto the living or dead cell biomass. The result can be a reduction in the effective dosage of the chemical, leading to an over-estimation of the tolerance of the 
organism to the chemical. Thus, it is desirable to use minimal biomass levels in these tests so that the dosage and toxic effect of chemicals can be assumed to be constant (Nyholm and Peterson, 1997; Peterson and Nyholm, 1993). If the chemicals being tested are volatile, then it is also important that the testing be performed in sealed vessels with minimal headspace, which may limit the volume of sample that can be withdrawn. Larger sample volumes would affect the headspace and potentially alter the results of the chemical inhibition test Unfortunately, many cell quantification methods are not very accurate at low cell densities and with low sample volumes, and this may be more problematic if one is trying to assess viable cell numbers, rather than total cell biomass.

To determine which viability assay was the most accurate and reproducible under low cell density conditions, we evaluated absorbance, chlorophyll $\alpha$, and fluorescence from SYTO $^{\circledR} 9$ in chemical inhibition tests involving farnesene Farnesene is a long-chain hydrocarbon that filamentous cyanobacteria are capable of being genetically engineered to produce (Halfmann et al., 2014b) The antimicrobial property of farnesene, generally as a component of plant oil, is well established (Agnihotri et al., 2011; Aligiannis et al., 2004; Caccioni et al. 1998; Gudžić et al., 2002; Lopes-Lutz et al., 2008). Farnesene has many applications including biofuels, lubricants, cosmetics, and fragrances (Buijs $\boldsymbol{e}$ al., 2013; Halfmann et al., 2014b), thus would be a valuable product of an industrial strain of filamentous cyanobacteria. We hypothesized that the fluorescence assay would provide necessary sensitivity compared to absorbance and chlorophyll $\alpha$ when biomass content and sample volumes are low.

Figure 5 shows the comparison of 3 cell quantification methods [2 for quantifying viable cells (SYTO ${ }^{\circledR} 9$ fluorescence and chlorophyll content) and 1 for quantifying total cells (absorbance)] for screening cyanobacteria in BG11 medium containing $0.5 \mathrm{~g} / \mathrm{L} \mathrm{NaHCO}_{3}$ as a carbon source and $0.032 \mathrm{~g} / \mathrm{L}$ of farnesene. For each method, growth of a wildtype Anabaena 7120 strain was compared to a putative mutant Anabaena 7120 strain previously acclimated to tolerate $0.32 \mathrm{~g} / \mathrm{L}$ farnesene (A7120.(0.32t).farn). A lower titer of farnesene $(0.032$ $\mathrm{g} / \mathrm{L})$ was used compared to what the strain was able to tolerate $(0.32 \mathrm{~g} / \mathrm{L})$, as this allowed for monitoring growth rather than just survivability. These trials used a low density starting cell inoculum, and were conducted in sealed test tubes where sample volume was limited to $100 \mu$ d daily samples. The test tubes contained 27 $\mathrm{ml}$ culture, thus the small daily samples had minimal impact on the headspace of the vessel and the concentration of biomass in the test tube.
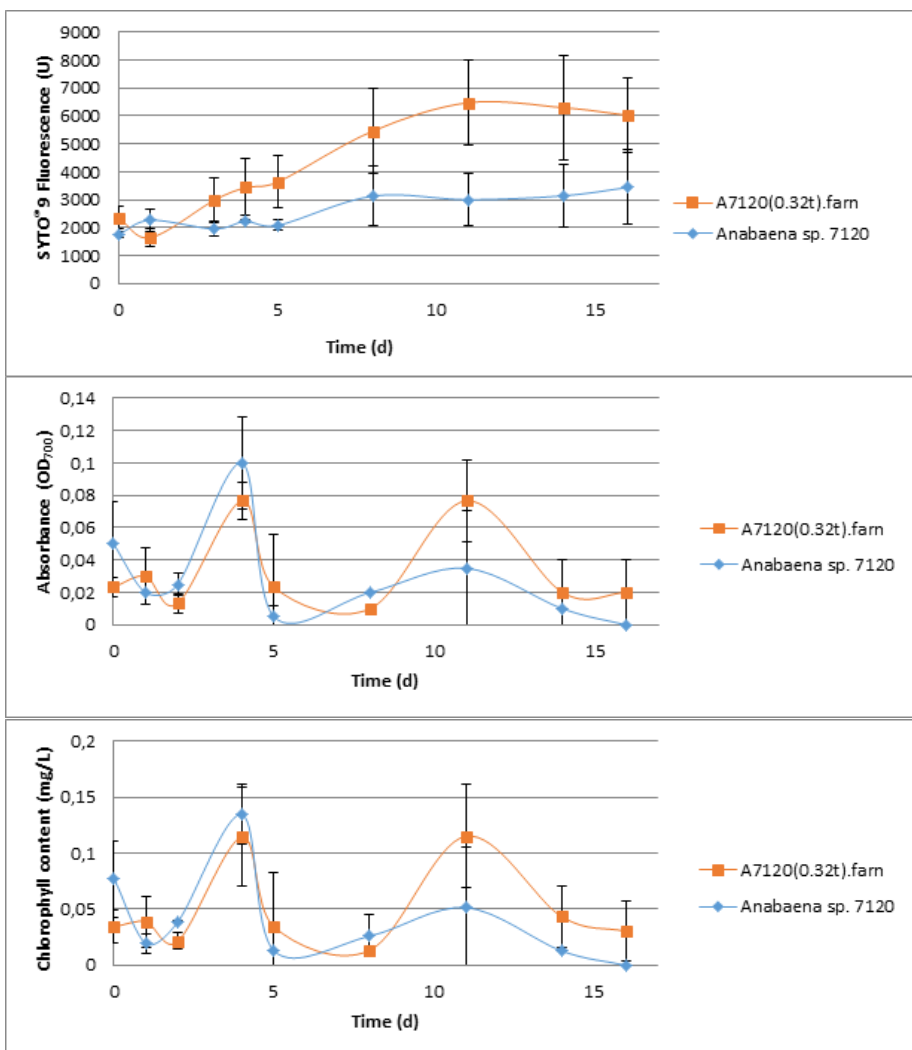

Figure 5 Comparison of three cell quantification methods for monitoring cyanobacteria growth at low cell densities and sample volumes. Each trial was completed in triplicate. Error bars represent the standard deviation.

All samples for all assays were taken from the same tube at the same time in these trials. As only $100 \mu \mathrm{l}$ samples were taken, the cultures had to be diluted with BG11 in order to have enough volume to accurately use the spectrophotometer. Fluorescence from SYTO $^{\circledR} 9$ was the only method that provided typical growth curves under these conditions of low cell density and small sample size. Even though the error bars are large in the SYTO ${ }^{\circledR} 9$ plot, the assay was still able to distinguish a difference between the acclimated strain and the wildtype. As the daily sample size was limited, it was necessary to dilute the sample to obtain sufficient volumes for measurements in the spectrophotometer, which likely diluted the biomass (measured as absorbance) and chlorophyll $a$ levels to or below the sensitivity level of the spectrophotometer. Presumably, this is at least partially responsible for the high degree of variability shown in the absorbance and chlorophyll $\alpha$ plots. The large error bars in Fig. 5 probably occurred due to the small biomass levels. Any amount of random or experimenta error with values that low would yield large error bars. Further evidence that low biomass content caused the large error bars can be observed by comparing Fig. 5 to Fig. 4, which had greater biomass content. The error bars are much smaller in Fig. 4 even though the method for measuring viability was identical.

As mentioned earlier, high cell densities will yield inaccurate results in chemical inhibition tests, thus the biomass concentration must be kept to a minimum. The conclusion reached in this part of the study concurs with a study by Mayer et al. (1997), that states that absorbance is considered to have borderline sensitivity and precision at the low biomass levels required for toxicity tests. All 3 growth parameter measurements were taken from the same culture at the same time, thus fluorescence from $\mathrm{SYTO}^{\circledR} 9$ is a superior method when cell density and/or sample size are limited.

\section{Assessing cell viability in photobioreactors}

It was previously shown in this study (Fig. 4) that absorbance (total cell biomass) and the fluorescence assay (viable cell biomass) are capable of quantifying cyanobacterial growth when biomass and sample volumes are not limited. We postulated the fluorescence assay would be a preferred alternative to absorbance, because the former only measures viable cells. There is also the potential to use smaller sample volumes and detect smaller differences in cell numbers. Therefore, we evaluated the use of the fluorescence assay to monitor viable cyanobacterial cells in $40 \mathrm{~L}$ PBR trials that compared various cultivation media. Figure 6 shows the effect of different cultivation media on the growth of Anabaena 7120 as measured by fluorescence from $S_{Y T O}{ }^{\circledR} 9$. The definitions for the 3 growth parameters measured from the fluorescence assay are as follows: maximum viability is the maximum fluorescence value during a trial, percent increase in viability is the final fluorescence divided by the initial fluorescence, and viability rate of change is the maximum viability divided by the incubation time. The 3 parameters measured allowed for a more robust analysis of the dynamics of filamentous cyanobacterial growth. In all cases, BG11 (contains sodium nitrate) resulted in the most growth. Tap water resulted in the leas growth, and BG11 supplemented with urea $\left(\mathrm{BG} 11_{\mathrm{U}}\right)$ and $\mathrm{BG} 11$ with no combined nitrogen source $\left(B G 11_{0}\right)$ were statistically similar. Replacing sodium nitrate with urea resulted in reduced growth compared to BG11 in 2 of the 3 parameters measured. Cultivating Anabaena 7120 in BG11 supplemented with urea rather than sodium nitrate also led to decreased growth in studies by Wang and Liu, (2003) and Johnson et al., 2016b. The results of this experiment allowed us to conclude that $\mathrm{SYTO}^{\circledR} 9$ was capable of detecting differences in cyanobacterial growth due to differences in growth media. Thus, this assay is an attractive option for industrial microbiologists interested in evaluating large-scale processes involving filamentous cyanobacteria.
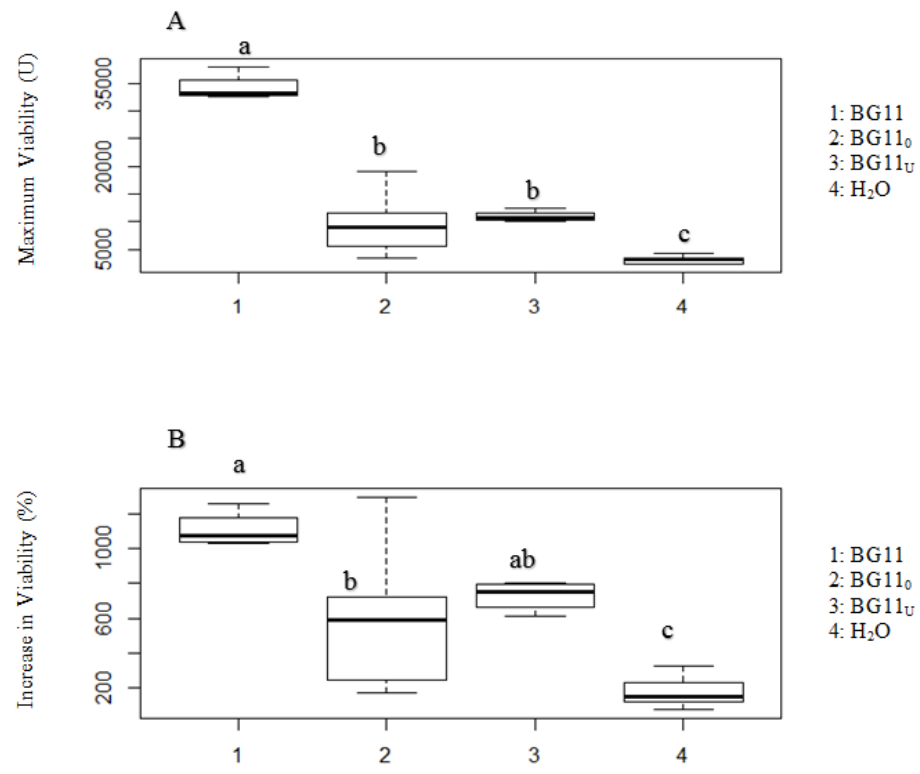
$\mathrm{C}$

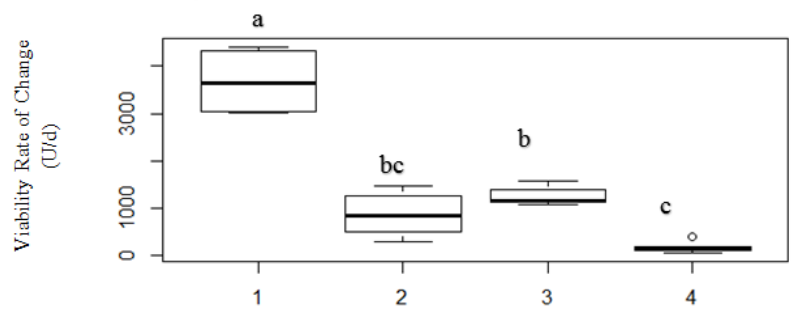

Figure 6 Comparison of different cultivation media on 3 growth parameters of Anabaena sp. PCC 7120 using fluorescence from SYTO ${ }^{\circledR} 9$ as a viable cell indicator. Each trial contained $\leq 4$ replicates. A: maximum viability during a trial $\mathrm{B}$ : percent increase in viability; C: viability rate of change. Different lower case letters indicate a statistical difference occurred among the treatments as determined by a Tukey's test. BG11: standard cyanobacterial growth medium containing sodium nitrate; BG11 $1_{0}$ : BG11 with no combined nitrogen source; BG11 $1_{\mathrm{U}}$ : BG11 supplemented with urea rather than sodium nitrate; $\mathrm{H}_{2} \mathrm{O}$ : tap water.

\section{CONCLUSIONS}

The study described herein showed that $\mathrm{SYTO}^{\circledR} 9$ is a reliable and accurate indicator of filamentous cyanobacteria viability. SYTOX ${ }^{\circledR}$ Blue did not work as a non-viable cell indicator in filamentous cyanobacteria and led to erroneous results similar to those we previously reported for the non-viable cell indicator PI (Johnson et al., 2015). Thus, it can be assumed that the other SYTOX ${ }^{\circledR}$ Dead Cell Stains will also not work as non-viable cell indicators in filamentous cyanobacteria because they have the same mode of action. Potentially, this could be caused by the intercellular modes of transporting nutrients, allowing PI and SYTOX $^{\mathbb{B}}$ Blue to penetrate viable cell membranes. Determining the cause of nonspecific binding of non-viable cell indicators in filamentous cyanobacteria is a future direction of this research. Microscopic evidence of non-specific binding of PI in filamentous cyanobacteria can be observed in a study by Johnson et al. (2015). Autofluorescence from light harvesting pigments was also not a practica method to monitor viability, presumably due to the intensity of fluorescence from the pigments not relating to the relative percentages of viable vs. non-viable cyanobacterial cells.

Fluorescence from SYTO ${ }^{\circledR} 9$ is preferred for monitoring viability of filamentous cyanobacteria under conditions of low biomass concentrations compared to absorbance and chlorophyll $\alpha$. A sealed system with low biomass content is needed for various applications, such as screening mutants for increased tolerance to next-generation biofuels. Small sample volumes should also be taken in these tests so that the headspace of the system does not affect the chemical titer in solution. With small sample volumes and the low biomass content, it is no possible to obtain accurate absorbance and chlorophyll $\alpha$ content results However, it is possible to use $\mathrm{SYTO}^{\circledR} 9$ as a viability indicator under these conditions.

In 40 L PBR trials where sample size was not limited, fluorescence from SYTO 9 was capable of detecting differences in cyanobacterial growth caused by differences in growth media. We believe this method is preferred compared to absorbance due to the fluorescence assay's capability of measuring only viable cells, whereas absorbance measures total cells and cell debris. The results of this study and our prior work (Johnson et al. 2015) show that $S_{Y T O}{ }^{\circledR} 9$ is a reliable accurate indicator of viable cells in filamentous cyanobacteria. While this study only used Anabaena 7120, it is a model species for filamentous cyanobacteria (Bryant, 2006; Rippka et al., 1979). Also, previous work by our research group investigating a fluorescence assay used several filamentous cyanobacteria strains, including Anabaena 7120, and they all produced identical results with respect to the fluorescence assay (Johnson $\boldsymbol{e t}$ al., 2015). Thus, we are confident the results of this study are applicable to other strains of filamentous cyanobacteria. Measuring fluorescence from $\mathrm{SYTO}^{\circledR} 9$ in a microplate reader allows for high-throughput data collection, which further adds to its potential. Applications of the SYTO ${ }^{\circledR} 9$ described in this study include monitoring cultures in PBR systems and screening mutants for increased tolerance to next-generation biofuels.

Acknowledgements: This work was supported by the South Dakota Agricultural Experiment Station under grant SD00H398-11 (to W.G.). This work was also partially supported by NASA under award No. NNX11AM03A (to W.G), USDA-SBIR grant 2012-33610-19524, North Central Sun Grant/DOT award No. DTOS59-07-G-00054, and the NSF-Energy for Sustainability Gran CBET1133951 (to R. Z.). We acknowledge use of the South Dakota State University Functional Genomics Core Facility supported in part by NSF/EPSCoR Grant No. 0091948 and by the State of South Dakota. The authors would also like to acknowledge the guidance and assistance of Dr. Huilan Zhu and Charles Halfmann throughout this study.

\section{REFERENCES}

Adav, S. S., Lee, D.-J., and Ren, N. (2007a). Biodegradation of pyridine using aerobic granules in the presence of phenol. Water Research, 41(13), 2903-2910. http://dx.doi.org/10.1016/j.watres.2007.03.038

Adav, S. S., Chen, M. Y., Lee, D. J., and Ren, N. Q. (2007b). Degradation of phenol by aerobic granules and isolated yeast Candida tropicalis. Biotechnology and Bioengineering, 96(5), 844-852. http://dx.doi.org/10.1002/bit.21148

Adav, S. S., and Lee, D.-J. (2008). Extraction of extracellular polymeric substances from aerobic granule with compact interior structure. Journal of Hazardous Materials, 154(1),

$1120-1126$ http://dx.doi.org/10.1016/j.jhazmat.2007.11.058

Agnihotri, S., Wakode, S., and Ali, M. (2011). Chemical composition, antimicrobial and topical anti-inflammatory activity of Valeriana jatamans Jones. essential oil. Journal of Essential Oil Bearing Plants, 14(4), 417-422. http://dx.doi.org/10.1080/0972060x.2011.10643596

Aiken, J. (1981). A chlorophyll sensor for automatic, remote operation in the marine environment. Marine Ecology Progress Series, 4(2), 235-239. http://dx.doi.org/10.3354/meps004235

Aligiannis, N., Kalpoutzakis, E., Kyriakopoulou, I., Mitaku, S., and Chinou, I. (2004). Essential oils of Phlomis species growing in Greece: chemical composition and antimicrobial activity. Flavour and Fragrance Journal, 19(4), 320-324. http://dx.doi.org/10.1002/ffj.1305

Allen, M. M., and Stanier, R. Y. (1968). Selective isolation of blue-green algae from water and soil. Journal of General Microbiology, 51(2), 203-209. http://dx.doi.org/10.1099/00221287-51-2-203

Asai, T., Matsukawa, T., and Kajiyama, S. i. (2016). Metabolic changes in Citrus leaf volatiles in response to environmental stress. Journal of Bioscience and Bioengineering, 121(2), 235-241. http://dx.doi.org/10.1016/j.jbiosc.2015.06.004 Baier, K., Lehmann, H., Stephan, D. P., and Lockau, W. (2004). NblA is essential for phycobilisome degradation in Anabaena sp. strain PCC 7120 but not for development of functional heterocysts. Microbiology, 150(8), 2739-2749. http://dx.doi.org/10.1099/mic.0.27153-0

Bridier, A., Hammes, F., Canette, A., Bouchez, T., and Briandet, R. (2015) Fluorescence-based tools for single-cell approaches in food microbiology. International Journal of Food Microbiology, 213, 2-16 http://dx.doi.org/10.1016/j.ijfoodmicro.2015.07.003

Bryant, D. A. (2006). The molecular biology of cyanobacteria (Vol. 1): Springer Science \& Business Media. http://dx.doi.org/10.1007/978-94-011-0227-8

Buijs, N. A., Siewers, V., and Nielsen, J. (2013). Advanced biofuel production by the yeast Saccharomyces cerevisiae. Current Opinion in Chemical Biology, 17(3), 480-488. http://dx.doi.org/10.1016/j.cbpa.2013.03.036

Caccioni, D. R., Guizzardi, M., Biondi, D. M., Renda, A., and Ruberto, G. (1998). Relationship between volatile components of citrus fruit essential oils and antimicrobial action on Penicillium digitatum and Penicillium italicum. International Journal of Food Microbiology, 43(1), 73-79. http://dx.doi.org/10.1016/s0168-1605(98)00099-3

Caiola, M. G., Billi, D., and Friedmann, E. I. (1996). Effect of desiccation on envelopes of the cyanobacterium Chroococcidiopsis sp.(Chroococcales) European Journal of Phycology, 31(1), 97-105. http://dx.doi.org/10.1080/09670269600651251

Chen, C.-Y., Yeh, K.-L., Aisyah, R., Lee, D.-J., and Chang, J.-S. (2011) Cultivation, photobioreactor design and harvesting of microalgae for biodiesel production: a critical review. Bioresource Technology, 102(1), 71-81. http://dx.doi.org/10.1016/j.biortech.2010.06.159

Chen, M.-Y., Lee, D.-J., Tay, J.-H., and Show, K.-Y. (2007). Staining of extracellular polymeric substances and cells in bioaggregates. Applied Microbiology and $\quad$ Biotechnology, 75(2), 467-474. http://dx.doi.org/10.1007/s00253-006-0816-5

Dagnino, D., De Abreu Meireles, D., and De Aquino Almeida, J. C. (2006) Growth of nutrient-replete Microcystis PCC 7806 cultures is inhibited by an extracellular signal produced by chlorotic cultures. Environmental Microbiology, 8(1), 30-36. http://dx.doi.org/10.1111/j.1462-2920.2005.00866.x

De Mendiburu, F. (2014). Agricolae: statistical procedures for agricultural research. $R$ package version 1.

Estevez, A. Y., Pritchard, S., Harper, K., Aston, J. W., Lynch, A., Lucky, J. J., .

Erlichman, J. S. (2011). Neuroprotective mechanisms of cerium oxide nanoparticles in a mouse hippocampal brain slice model of ischemia. Free Radical Biology and Medicine, 51(6), 1155-1163. http://dx.doi.org/10.1016/j.freeradbiomed.2011.06.006

Faul, F., Erdfelder, E., Lang, A.G., and Buchner, A. (2007). G*Power3: a flexible statistical power analysis program for the social, behavioral, and biomedical sciences. Behavior Research Methods, 39(2), 175-191. http://dx.doi.org/10.3758/BF03193146

Filoche, S. K., Coleman, M. J., Angker, L., and Sissons, C. H. (2007). A fluorescence assay to determine the viable biomass of microcosm dental plaque biofilms. Journal of Microbiological Methods, 69(3), 489-496. http://dx.doi.org/10.1016/j.mimet.2007.02.015

Gryliuk, G., Rätsep, M., Hildebrandt, S., Irrgang, K.-D., Eckert, H.-J., and Pieper, J. (2014). Excitation energy transfer and electron-vibrational coupling in 
phycobiliproteins of the cyanobacterium Acaryochloris marina investigated by site-selective spectroscopy. Biochimica et Biophysica Acta (BBA)-Bioenergetics, 1837(9), 1490-1499. http://dx.doi.org/10.1016/j.bbabio.2014.02.010

Gu, L., Xiang, X., Raynie, D., Gibbons, W., and Zhou, R. (2012). Biosolar Conversion of $\mathrm{CO} 2$ and $\mathrm{H} 2 \mathrm{O}$ to Long-chain Alcohols by Engineered Cyanobacteria. Paper presented at the Proceedings From Sun Grant National Conference: Science for Biomass Feedstock Production and Utilization, New Orleans, LA.

Gudžić, B., Djokovic, D., Vajs, V., Palić, R., and Stojanovic, G. (2002) Composition and antimicrobial activity of the essential oil of Hypericum maculatum Crantz. Flavour and Fragrance Journal, 17(5), 392-394. http://dx.doi.org/10.1002/ffj.1112

Guoce, Y., Dingji, S., Zhaoling, C., Wei, C., and Ouyang, F. (2011). Growth and physiological features of cyanobacterium Anabaena sp. strain PCC 7120 in a glucose-mixotrophic culture. Chinese Journal of Chemical Engineering, 19(1), 108-115. http://dx.doi.org/10.1016/s1004-9541(09)60185-3

Guzmán, E., Baeten, V., Pierna, J. A. F., and García-Mesa, J. A. (2015) Evaluation of the overall quality of olive oil using fluorescence spectroscopy. $\begin{array}{lll}\text { Food Chemistry, } & \text { 173, 927-934 }\end{array}$ http://dx.doi.org/10.1016/i.foodchem.2014.10.041

Hailing-Sørensen, B., Nyhohn, N., and Baun, A. (1996). Algal toxicity tests with volatile and hazardous compounds in air-tight test flasks with $\mathrm{CO} 2$ enriched headspace. Chemosphere, 32(8), 1513-1526. http://dx.doi.org/10.1016/00456535(96)00059-8

Halfmann, C., Gu, L., and Zhou, R. (2014a). Engineering cyanobacteria for the production of a cyclic hydrocarbon fuel from $\mathrm{CO} 2$ and $\mathrm{H} 2 \mathrm{O}$. Green Chemistry, 16(6), 3175-3185. http://dx.doi.org/10.1039/c3gc42591f

Halfmann, C., Gu, L. P., Gibbons, W., and Zhou, R. B. (2014b). Genetically engineering cyanobacteria to convert $\mathrm{CO} 2$, water, and light into the long-chain hydrocarbon farnesene. Applied Microbiology and Biotechnology, 98(23), 98699877. http://dx.doi.org/10.1007/s00253-014-6118-4

Jin, H., Chen, L., Wang, J., and Zhang, W. (2014). Engineering biofuel tolerance in non-native producing microorganisms. Biotechnology Advances, 32(2), 541 548. http://dx.doi.org/10.1016/j.biotechadv.2014.02.001

Johnson, M. B., and Criss, A. K. (2013). Fluorescence microscopy methods for determining the viability of bacteria in association with mammalian cells. JoVE (Journal of Visualized Experiments) 79, 50729. http://dx.doi.org/10.3791/50729

Johnson, T. J., Hildreth, M. B., Gu, L., Zhou, R., and Gibbons, W. R. (2015) Testing a dual-fluorescence assay to monitor the viability of filamentous cyanobacteria. Journal of Microbiological Methods, 113, 57-64. http://dx.doi.org/10.1016/j.mimet.2015.04.003

Johnson, T.J., Halfmann, C., Zahler, J.D., Zhou, R., and Gibbons, W.R. (2016a) Increasing the tolerance of filamentous cyanobacteria to next-generation biofuels via directed evolution. Algal Research, 18, 250-256. http:// dx.doi:10.1016/i.algal.2016.06.023

Johnson, T.J., Jahandideh, A., Isaac, I.C., Baldwin, E.L., Muthukumarappan, K., and Gibbons, W.R. (2016b). Determining the optimal nitrogen source for larbescale cultivation of filamentous cyanobacteria. Journal of Applied Phycology, 113. http://dx.doi.org/10.1007/s10811-016-0923-3

Johnson, T.J., Zahler, J.D., Baldwin, E.L., Zhou, R., and Gibbons, W.R. (2016c). Optimizing cyanobacteria growth conditions in a sealed environment to enable chemical inhibition tests with volatile chemicals. Journal of Microbiological Methods, 126, 54-59. http://dx.doi.org/10.1016.j.mimet.2016.05.011

Krause, M., Radt, B., Rösch, P., and Popp, J. (2007). The investigation of single bacteria by means of fluorescence staining and Raman spectroscopy. Journal of Raman Spectroscopy, 38(4), 369-372. http://dx.doi.org/10.1002/jrs.1721

Lee, D. Y., and Rhee, G. (2001). The effect of 2, 5, 2', 5'-tetrachlorobiphenyl on growth and death of the cyanobacterium Anabaena flos-aquae. Environmental $\begin{array}{llll}\text { Toxicology and Chemistry, 20(10), 2189-2192. } & \end{array}$ http://dx.doi.org/10.1002/etc.5620201009

Lichtenthaler, H., Buschmann, C., Rinderle, U., and Schmuck, G. (1986) Application of chlorophyll fluorescence in ecophysiology. Radiation and Environmental Biophysics, 25(4), 297-308. http://dx.doi.org/10.1007/bf01214643 Lopes-Lutz, D., Alviano, D. S., Alviano, C. S., and Kolodziejczyk, P. P. (2008) Screening of chemical composition, antimicrobial and antioxidant activities of Artemisia essential oils. Phytochemistry, 69(8), 1732-1738. http://dx.doi.org/10.1016/j.phytochem.2008.02.014

Lozano, V. A., de la Peña, A. M., Durán-Merás, I., Mansilla, A. E., and Escandar, G. M. (2013). Four-way multivariate calibration using ultra-fast highperformance liquid chromatography with fluorescence excitation-emission detection. Application to the direct analysis of chlorophylls $a$ and $b$ and pheophytins $\mathrm{a}$ and $\mathrm{b}$ in olive oils. Chemometrics and Intelligent Laboratory Systems, 125, 121-131. http://dx.doi.org/10.1016/j.chemolab.2013.04.005 Lu, J., Turnbull, L., Burke, C. M., Liu, M., Carter, D. A., Schlothauer, R. C., Harry, E. J. (2014). Manuka-type honeys can eradicate biofilms produced by Staphylococcus aureus strains with different biofilm-forming abilities. PeerJ, 2 , 326. http://dx.doi.org/10.7717/peerj.326

Machado, I. M., and Atsumi, S. (2012). Cyanobacterial biofuel production $\begin{array}{llrl}\text { Journal of } & \text { Biotechnology, } & \text { 162(1), }\end{array}$ http://dx.doi.org/10.1016/j.jbiotec.2012.03.005
Magajna, B. A., and Schraft, H. (2015). Campylobacter jejuni biofilm cells become viable but non-culturable (VBNC) in low nutrient conditions at $4^{\circ} \mathrm{C}$ more quickly than their planktonic counterparts. Food Control, 50, 45-50. http://dx.doi.org/10.1016/j.foodcont.2014.08.022

Mayer, P., Cuhel, R., and Nyholm, N. (1997). A simple in vitro fluorescence method for biomass measurements in algal growth inhibition tests. Water Research, 31(10), 2525-2531. http://dx.doi.org/10.1016/s0043-1354(97)00084-5

Mayer, P., Nyholm, N., Verbruggen, E. M., Hermens, J. L., and Tolls, J. (2000) Algal growth inhibition test in filled, closed bottles for volatile and sorptive materials. Environmental Toxicology and Chemistry, 19(10), 2551-2556. http://dx.doi.org/10.1002/etc.5620191022

Molecular Probes. (2004). Invitrogen Molecular Probes. LIVE/DEAD ${ }^{\circledR}$ BacLight $^{\mathrm{TM}}$ bacterial viability kits. Manuals and products inserts http://tools.life.technologies.com/content/sfs/manuals/mp07007.pdf

Mullineaux, C.W., Mariscal, V., Nenninger, A., Khanum, H., Herrero, A., Flores, E., and Adams, D.G. (2008). Mechanism of intercellular molecular exchange in heterocyst-forming cyanobacteria. The EMBO Journal, 27(9), 1299-1308. http://dx.doi.org/10.1038/emboj.2008.66

Nyholm, N., and Peterson, H. G. (1997). Laboratory bioassays with microalgae CRC Press: Boca Raton, FL. http://dx.doi.org/10.1201/9781420048711.ch9

Ogawa, T., and Sonoike, K. (2015). Dissection of respiration and photosynthesis in the cyanobacterium Synechocystis sp. PCC6803 by the analysis of chlorophyll fluorescence. Journal of Photochemistry and Photobiology B: Biology, 144, 6167. http://dx.doi.org/10.1016/j.jphotobiol.2015.02.005

Peterson, H. G., and Nyholm, N. (1993). Algal Bioassays for Metal Toxicity Identification. Water Quality Research Journal of Canada, 28(1), 129-153.

R Core Team. (2013). ISBN 3-900051-07-0. http://www.r-project.org

Rippka, R., Deruelles, J., Waterbury, J. B., Herdman, M., and Stanier, R. Y. (1979). Generic assignments, strain histories and properties of pure cultures of cyanobacteria. Journal of General Microbiology, 111(1), 1-61. http://dx.doi.org/10.1099/00221287-111-1-1

Ruther, J., and Hilker, M. (1998). A versatile method for on-line analysis of volatile compounds from living samples. Journal of Chemical Ecology, 24(3), 525-534. http://dx.doi.org/10.1023/a:1022316903849

Sarchizian, I., and Ardelean, I. I. (2012). Quantification of cells capable of grwoth and multiplication using direct viable count method on filamentous and unicellular cyanobacteria. International Multidisciplinary Scientific GeoConference: SGEM: Surveying Geology \& mining Ecology Management, 5 , 655. http://dx.doi.org/10.5593/sgem2012/s20.v5088

Sato, M., Murata, Y., Mizusawa, M., Iwahashi, H., and Oka, S.-i. (2004). A simple and rapid dual-fluorescence viability assay for microalgae. Microbiology and Culture Collections, 20(2), 53e9.

Schoepp, N. G., Stewart, R. L., Sun, V., Quigley, A. J., Mendola, D., Mayfield, S. P., and Burkart, M. D. (2014). System and method for research-scale outdoor production of microalgae and cyanobacteria. Bioresource Technology, 166, 273 281. http://dx.doi.org/10.1016/j.biortech.2014.05.046

Shi, L., Günther, S., Hübschmann, T., Wick, L. Y., Harms, H., and Müller, S. (2007). Limits of propidium iodide as a cell viability indicator for environmental $\begin{array}{llll}\text { bacteria. } & \text { Cytometry } & \text { Part } & \text { 51(8), }\end{array}$ http://dx.doi.org/10.1002/cyto.a.20402

Stiefel, P., Schmidt-Emrich, S., Maniura-Weber, K., and Ren, Q. (2015). Critical aspects of using bacterial cell viability assays with the fluorophores SYTO9 and $\begin{array}{llll}\text { propidium iodide. } & B M C & \text { Microbiology, } & 15(1), \quad 36 .\end{array}$ http://dx.doi.org/10.1186/s12866-015-0376-X

Tashyreva, D., Elster, J., and Billi, D. (2013). A novel staining protocol for multiparameter assessment of cell heterogeneity in Phormidium populations (cyanobacteria) employing fluorescent dyes. PloS One, 8(2), 55283 http://dx.doi.org/10.1371/journal.pone.0055283

Truernit, E., and Haseloff, J. (2008). A simple way to identify non-viable cells within living plant tissue using confocal microscopy. Plant Methods, 4(1), 15 http://dx.doi.org/10.1186/1746-4811-4-15

Von Blottnitz, H., and Curran, M. A. (2007). A review of assessments conducted on bio-ethanol as a transportation fuel from a net energy, greenhouse gas, and environmental life cycle perspective. Journal of Cleaner Production, 15(7), 607 619. http://dx.doi.org/10.1016/j.jclepro.2006.03.002

Wang, X., and Liu, L. (2003). Effects of the different nitrogen, phosphorous and carbon source on the growth and glycogen reserves in Synechocystis and Anabaena. African Journal of Microbiology Research, 7(23), 2820-2827. http://dx.doi.org/10.5897/AJMR2013.5787.

Wickham, H. (2012). Reshape2: flexibility reshape data: a reboot of the reshape package. R package version 2012.

Yagüe, P., Manteca, A., Simon, A., Diaz-Garcia, M. E., and Sanchez, J. (2010) New method for monitoring programmed cell death and differentiation in submerged Streptomyces cultures. Applied and Environmental Microbiology, 76(10), 3401-3404. http://dx.doi.org/10.1128/aem.00120-10

Zeidán-Chuliá, F., Keskin, M., Könönen, E., Uitto, V.-J., Söderling, E., Moreira J. C. F., and Gürsoy, U. K. (2015). Antibacterial and antigelatinolytic effects of Satureja hortensis L. essential oil on epithelial cells exposed to Fusobacterium nucleatum. Journal of Medicinal Food, 18(4), 503-506 http://dx.doi.org/10.1089/jmf.2013.0052 
Zhou, J., and Li, Y. (2010). Engineering cyanobacteria for fuels and chemicals production. Protein \& Cell, 1(3), 207-210. http://dx.doi.org/10.1007/s13238-0100043-9.

Zhu, T., and Xu, X. (2013). Efficacy of a dual fluorescence method in detecting the viability of overwintering cyanobacteria. Letters in Applied Microbiology, 57(3), 174-180. http://dx.doi.org/10.1111/lam.12095 